\title{
Oxidation reactions of an anionic gallium(I) N-heterocyclic carbene analogue with group 16 compounds
}

\author{
Robert J. Baker, Cameron Jones* and Marc Kloth \\ School of Chemistry, Main Building, Cardiff University, Cardiff, CF10 3AT, U.K. \\ E-mail: Jonesca6@cardiff.ac.uk
}

Received 12th April 2005, Accepted 11th May 2005

First published as an Advance Article on the web 23rd May 2005

\begin{abstract}
The reactivity of an anionic gallium(I) heterocycle, $[\mathrm{K}(\mathrm{tmeda})]\left[\mathrm{Ga}\left\{[\mathrm{N}(\mathrm{Ar}) \mathrm{C}(\mathrm{H})]_{2}\right\}\right], \mathrm{Ar}=\mathrm{C}_{6} \mathrm{H}_{3} \operatorname{Pr}_{2}{ }_{2}-2,6$, towards sources of elemental chalcogens and diorgano-dichalcogenides has been investigated and comparisons drawn with the reactivity of the valence isoelectronic $\mathrm{N}$-heterocyclic carbene class of ligand. The reactions of the heterocycle with $\mathrm{N}_{2} \mathrm{O}$ or $(\mathrm{Te}) \mathrm{PEt}_{3}$ yielded the dimeric, dianionic gallium(III) complexes, $[\mathrm{K}(\mathrm{L})]_{2}\left[(\mu-\mathrm{E}) \mathrm{Ga}\left\{[\mathrm{N}(\mathrm{Ar}) \mathrm{C}(\mathrm{H})]_{2}\right\}\right]_{2}, \mathrm{E}=\mathrm{O}, \mathrm{L}=$ tmeda; $\mathrm{E}=\mathrm{Te}, \mathrm{L}=\mathrm{THF}$. Treatment of $[\mathrm{K}($ tmeda $)]\left[\mathrm{Ga}\left\{[\mathrm{N}(\mathrm{Ar}) \mathrm{C}(\mathrm{H})]_{2}\right\}\right]$ with the diphenyl dichalcogenides, $\mathrm{PhEEPh}$, $\mathrm{E}=\mathrm{Se}$ or Te, gave the one dimensional polymer, $\left[\mathrm{K}\left[(\mathrm{PhSe})_{2} \mathrm{Ga}\left\{[\mathrm{N}(\mathrm{Ar}) \mathrm{C}(\mathrm{H})]_{2}\right\}\right]\right]_{\infty}$ and the monomeric complex, $\left[\mathrm{K}\left(\mathrm{OEt}_{2}\right)_{3}\right]\left[(\mathrm{PhTe})_{2} \mathrm{Ga}\left\{[\mathrm{N}(\mathrm{Ar}) \mathrm{C}(\mathrm{H})]_{2}\right\}\right]$, respectively. The X-ray crystal structures of the four complexes are reported.
\end{abstract}

\section{Introduction}

Our group ${ }^{1}$ and that of Schmidbaur ${ }^{2}$ have reported the syntheses of the anionic gallium(I) heterocycles, $\left[: \mathrm{Ga}\left\{[\mathrm{N}(\mathrm{R}) \mathrm{C}(\mathrm{H})]_{2}\right\}\right]^{-}$, $\mathrm{R}=2$,6-diisopropylphenyl $\mathbf{1}$ or $\mathrm{Bu}^{\mathrm{t}}$, which are valence isoelectronic analogues of the important $\mathrm{N}$-heterocyclic carbene (NHC) class of ligand, viz.: $\mathrm{C}\left\{\left[\mathrm{N}(\mathrm{R}) \mathrm{C}\left(\mathrm{R}^{\prime}\right)\right]_{2}\right\}, \mathrm{R}^{\prime}=\mathrm{H}$, alkyl etc. In the past 10 years, the coordination chemistry of NHCs has been exhaustively studied and complexes with the majority of the non-radioactive metals are now known. ${ }^{3}$ Many of these have displayed activity as homogeneous catalysts in a number of synthetic processes, and some complexes are now commercially available for this purpose. Considering the importance of NHCs as ligands, we have embarked on a study to investigate the coordination chemistry of $\mathbf{1}$ toward s-, p- and d-block metals. ${ }^{4}$ In its early stages this has shown that there are parallels between the two ligand classes, and that like NHCs, 1 can stabilise metal fragments that are thermally labile and/or contain the metal in a low oxidation state. ${ }^{5}$ The stabilising ability of $\mathbf{1}$ is derived from its steric bulk and the very nucleophilic nature of the essentially sp-hybridised singlet lone pair at its gallium centre.

The reactivity of NHCs towards the non-metallic or metalloid elements, and compounds containing these elements, has not been studied in great detail but a number of important results have been forthcoming. For example, the reactions of NHCs with elemental sulfur, selenium or tellurium have been documented, and the properties and further chemistry of the resulting monomeric cyclic chalcogenoureas, $\left[(\mathrm{E}) \mathrm{C}\left\{\left[\mathrm{N}(\mathrm{R}) \mathrm{C}\left(\mathrm{R}^{\prime}\right)\right]_{2}\right\}\right], \mathrm{E}=$ $\mathrm{S}, \mathrm{Se}$ or $\mathrm{Te}$, have been investigated. ${ }^{3 d}$ Of particular note here is the excellent thermal stability of cyclic telluroureas derived from NHCs. ${ }^{6}$ This can be compared with that of most other tellurocarbonyl compounds, which are normally only isolated as metal complexes. It should also be mentioned that a silicon analogue of NHCs, : $\mathrm{Si}\left\{\left[\mathrm{N}\left(\mathrm{Bu}^{\mathrm{t}}\right) \mathrm{C}(\mathrm{H})\right]_{2}\right\}$, has recently been shown to react with sulfur or selenium to give the chalcogen bridged dimers, $\left[(\mu-\mathrm{E}) \mathrm{Si}\left\{\left[\mathrm{N}\left(\mathrm{Bu}^{\mathrm{t}}\right) \mathrm{C}(\mathrm{H})\right]_{2}\right\}\right]_{2}, \mathrm{E}=\mathrm{S}$ or $\mathrm{Se}^{7}$

In light of the stability of complexes derived from the reactions of NHCs with group 16 precursors, we believed it would be of interest to investigate the reactivity of 1 towards similar precursors. Although a variety of complexes between gallium and heavier chalcogenides are known, ${ }^{8}$ it was thought that the nucleophilicity and steric bulk of $\mathbf{1}$ could lead to stable complexes of low nuclearity. In this respect, it is worthy of mention that neutral gallium(I) heterocycles related to $\mathbf{1}$ have been successfully utilised to prepare the terminal chalcogenide complexes, $\left[\left(\mathrm{Tp}^{{ }^{\mathrm{B}} \mathrm{Bu}_{2}}\right) \mathrm{Ga}=\mathrm{E}\right]\left(\mathrm{Tp}^{\mathrm{t}_{\mathrm{Bu}}}=\operatorname{tris}(3,5\right.$-ditert-butyl)pyrazolylhydroborate; $\mathrm{E}=\mathrm{S}, \mathrm{Se}$ or $\mathrm{Te})^{9}$ and the chalcogenide bridged dimers, $\left[(\mu-\mathrm{E}) \mathrm{Ga}\left\{[\mathrm{N}(\mathrm{Ar}) \mathrm{C}(\mathrm{Me})]_{2} \mathrm{CH}\right\}\right]_{2}$ $(\mathrm{E}=\mathrm{O}$ or $\mathrm{S}){ }^{10}$ In addition, acyclic gallium(I) diyls, :GaR, are known to react with sources of elemental chalcogens to give higher nuclearity complexes, for example the tetrameric heterocage species, $\left[\mathrm{EGa}\left\{\mathrm{C}\left(\mathrm{SiMe}_{3}\right)_{3}\right\}\right]_{4}(\mathrm{E}=\mathrm{S}$, Se or Te $) .{ }^{11}$ Herein, we report the outcomes of the reactions of 1 with sources of the non-radioactive chalcogens and several dialkyl and diaryldichalcogenides.

\section{Results and discussion}

In the initial stages of this study it was observed that exposure of $[\mathrm{K}$ (tmeda) $][\mathbf{1}]$ to an excess of either dry air or $\mathrm{O}_{2}$ resulted in decomposition of the heterocycle and the recovery of the diazabutadiene, $\{\mathrm{N}(\mathrm{Ar})=\mathrm{C}(\mathrm{H})\}_{2}$, as the only isolable product. As a result, a more controllable route to the oxidation of the gallium(I) heterocycle was sought. To this end, its treatment with a stoichiometric amount of $\mathrm{N}_{2} \mathrm{O}$ gave rise to the dimeric, dianionic complex, 2, in a low isolated yield (Scheme 1). Attempts to extend this work by treating [K(tmeda)][1] with either elemental $\mathrm{S}$, Se or Te led to failure, as no reaction occurred in any case. The reasons for this lack of reactivity must include the low solubility of the chalcogen elements in the THF reaction solvent (in the case of $\mathrm{Se}$ and $\mathrm{Te}$ ) and the relative strength of the $\mathrm{S}-\mathrm{S}$ bonds in $\mathrm{S}_{8}$. It is noteworthy that the lack of reactivity of $[\mathrm{K}(\mathrm{tmeda})][1]$ towards elemental sulfur contrasts with the formation of the four- and eight-membered heterocycles, $\left[(\mu-\mathrm{S}) \mathrm{Ga}\left\{[\mathrm{N}(\mathrm{Ar}) \mathrm{C}(\mathrm{Me})]_{2} \mathrm{CH}\right\}\right]_{2}{ }^{10}$ and $\left[\left(\mu-\mathrm{S}_{3}\right) \mathrm{Al}\left\{[\mathrm{N}(\mathrm{Ar}) \mathrm{C}(\mathrm{Me})]_{2} \mathrm{CH}\right\}\right]_{2},{ }^{12}$ from the reactions of the neutral six-membered $\mathrm{Al}(\mathrm{I})$ and $\mathrm{Ga}(\mathrm{I})$ heterocycles, $\left[: \mathrm{M}\left\{[\mathrm{N}(\mathrm{Ar}) \mathrm{C}(\mathrm{Me})]_{2} \mathrm{CH}\right\}\right]$, with $\mathrm{S}_{8}$.

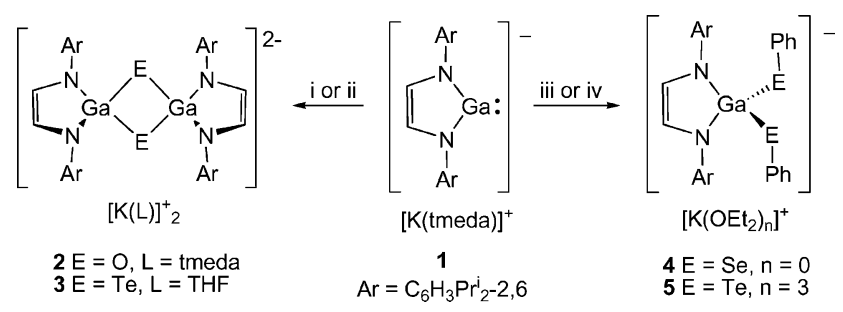

Scheme 1 (i) $\mathrm{N}_{2} \mathrm{O}, \mathrm{Et}_{2} \mathrm{O}$; (ii) (Te) $\mathrm{PEt}_{3}, \mathrm{THF}$; (iii) $\mathrm{Ph}_{2} \mathrm{Se}_{2}, \mathrm{Et}_{2} \mathrm{O}$; (iv) $\mathrm{Ph}_{2} \mathrm{Te}_{2}, \mathrm{Et}_{2} \mathrm{O}$.

To overcome this lack of reactivity, [K(tmeda)][1] was reacted with soluble sources of the atomic chalcogens. In the case of sulfur, the gallium heterocycle was treated with 1 equiv. 
of either propylene sulfide or $(\mathrm{S}) \mathrm{PPh}_{3}$, but both reactions led to intractable mixtures of products. Similarly, the reaction of $[\mathrm{K}($ tmeda $)][\mathbf{1}]$ with $(\mathrm{Se}) \mathrm{PEt}_{3}$ yielded an inseparable mixture of products, no components of which could be identified. More success was had in the reaction of (Te) $\mathrm{PEt}_{3}$ with the gallium heterocycle. This proceeded, in good yield, to the extremely air sensitive, yet thermally robust dimeric complex, $\mathbf{3}$, which is closely related to 2 .

The NMR spectra of $\mathbf{2}$ and $\mathbf{3}$ are consistent with their empirical formulae but shed little light on their degree of association. In the solid state this was determined by obtaining the X-ray crystal structures of the compounds (Figs. 1 and 2 respectively, Table 1). Complex $\mathbf{2}$ is dimeric and sits on a centre of inversion. The bridging oxide ligands have asymmetric interactions with the two gallium centres, giving rise to short $[1.814(3) \AA]$ and long

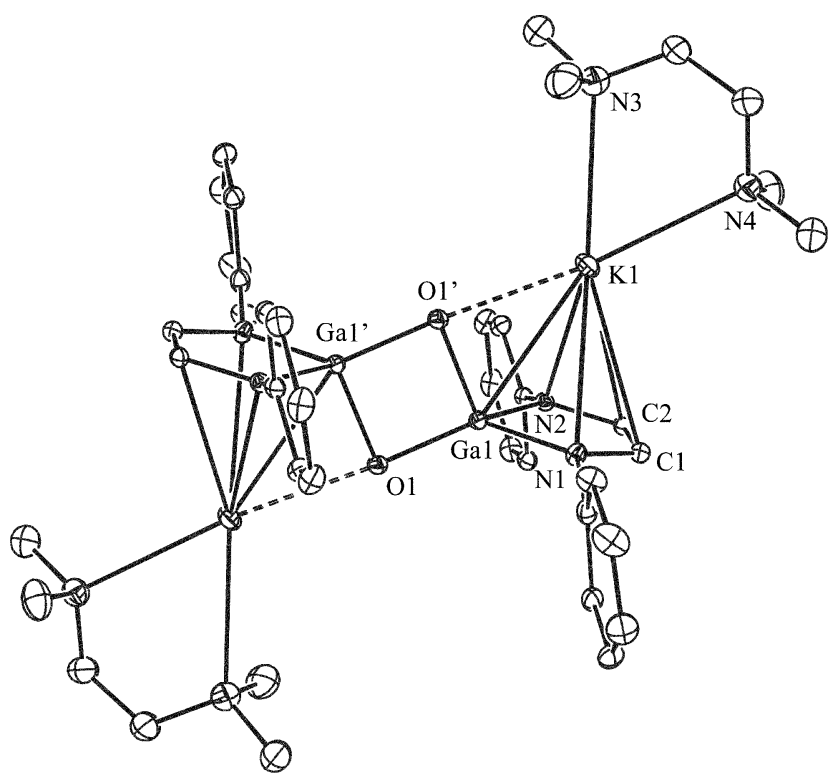

Fig. 1 Molecular structure of 2 (isopropyl groups removed for sake of clarity). Selected bond lengths $(\AA)$ and angles $\left({ }^{\circ}\right)$ : $\mathrm{Ga}(1)-\mathrm{O}(1) 1.814(3)$, $\mathrm{Ga}(1)-\mathrm{O}(1)^{\prime}$ 1.905(3), $\mathrm{Ga}(1)-\mathrm{N}(1)$ 1.924(4), $\mathrm{Ga}(1)-\mathrm{N}(2)$ 1.923(4), $\mathrm{Ga}(1)-\mathrm{K}(1) \quad 3.1383(16), \quad \mathrm{K}(1)-\mathrm{O}(1)^{\prime} \quad 2.584(3), \quad \mathrm{K}(1)-\mathrm{N}(4) \quad 2.883(5)$, $\mathrm{K}(1)-\mathrm{N}(3) 2.987(6), \mathrm{K}(1)-\mathrm{N}(1) 3.088(4), \mathrm{K}(1)-\mathrm{N}(2) 3.140(4), \mathrm{K}(1)-\mathrm{C}(1)$ $3.226(5), \mathrm{K}(1)-\mathrm{C}(2) 3.245(5), \mathrm{N}(1)-\mathrm{C}(1) 1.408(6), \mathrm{N}(2)-\mathrm{C}(2) 1.403(6)$ $\mathrm{C}(1)-\mathrm{C}(2)$ 1.346(7), O(1)-Ga(1)-O(1)' 91.00(14), Ga(1)-O(1)-Ga(1) 89.00(14), N(2)-Ga(1)-N(1) 87.67(16), Ga(1)-O(1)-K(1)' 176.04(17), $\mathrm{Ga}(1)^{\prime}-\mathrm{O}(1)-\mathrm{K}(1)^{\prime} 87.34(12)$. Symmetry operation used to generate equivalent atoms ': $-x+1,-y+1,-z$.

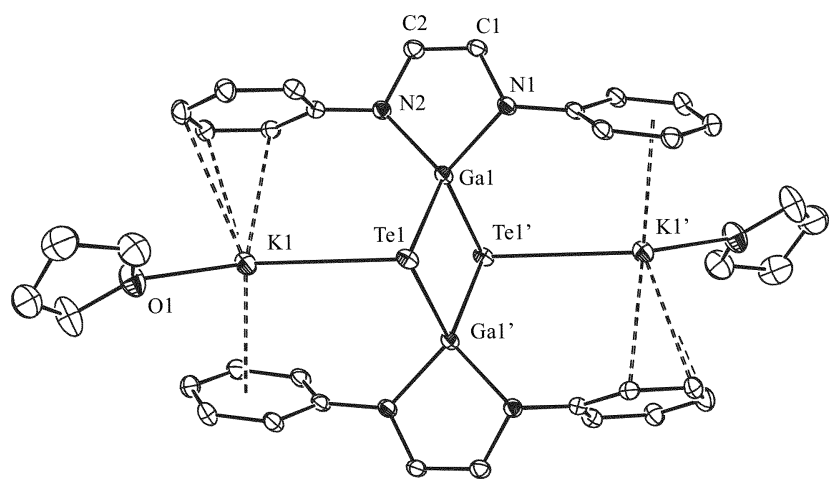

Fig. 2 Molecular structure of 3 (isopropyl groups removed for sake of clarity). Selected bond lengths (A) and angles $\left(^{\circ}\right)$ : $\mathrm{Ga}(1)-\mathrm{Te}(1)$ 2.6217(9), Ga(1)-Te(1)' 2.6135(10), Ga(1)-N(1) 1.932(4), Ga(1)-N(2) 1.919(4), $\quad \mathrm{Te}(1)-\mathrm{K}(1) \quad 3.5166(14), \quad \mathrm{K}(1)-\mathrm{O}(1) \quad 2.683(4), \quad \mathrm{C}(1)-\mathrm{C}(2)$ 1.335(7), N(1)-Ga(1)-N(2) 87.66(16), N(1)-Ga(1)-Te(1) 124.95(11), $\mathrm{N}(1)-\mathrm{Ga}(1)-\mathrm{Te}(1)^{\prime}$ 110.11(12), N(2)-Ga(1)-Te(1) 115.50(11), N(2)$\mathrm{Ga}(1)-\mathrm{Te}(1)^{\prime}$ 121.84(11), Te(1)'-Ga(1)-Te(1) 98.77(2), Ga(1)-Te(1)$\mathrm{Ga}(1)^{\prime} \quad 81.23(2), \quad \mathrm{Ga}(1)-\mathrm{Te}(1)-\mathrm{K}(1) \quad 92.41(3), \quad \mathrm{Ga}(1)^{\prime}-\mathrm{Te}(1)-\mathrm{K}(1)$ 93.19(3). Symmetry operation used to generate equivalent atoms' $:-x+$ $2,-y,-z+1$.
[1.905(3) $\AA] \mathrm{Ga}-\mathrm{O}$ bond lengths. The shortness of the former interactions could suggest they possess some $\mathrm{Ga}-\mathrm{O}$ double bond character involving $\pi$-donation from the oxygen centre to the empty $\mathrm{Ga}$ p-orbital. Indeed, they are the shortest $\mathrm{Ga}-\mathrm{O}$ interactions within $\mathrm{Ga}_{2} \mathrm{O}_{2}$ four-membered rings by some margin and can be compared to the $\mathrm{Ga}-\mathrm{O}$ distances in the related, more symmetrical dimers, $\left[(\mu-\mathrm{O}) \mathrm{Ga}\left\{[\mathrm{N}(\mathrm{Ar}) \mathrm{C}(\mathrm{Me})]_{2} \mathrm{CH}\right\}\right]_{2}[1.8536(9)$ and 1.8485(9) $\AA]^{10}$ and $\left[(\mathrm{THF})_{2} \mathrm{Li}(\mu-\mathrm{O}) \mathrm{Ga}(\mathrm{Mes})_{2}\right]_{2}$ (Mes = mesityl) $[1.897(3)$ and 1.898(3) $\mathrm{A}] \cdot{ }^{13}$ Moreover, the $\mathrm{Ga}-\mathrm{O}$ bonds in 2 are significantly shorter than that in the monomeric complex, [Mes* ${ }^{*} \mathrm{GaBu}_{2}^{\mathrm{t}}$ ] (Mes* $\left.=\mathrm{C}_{6} \mathrm{H}_{2} \mathrm{Bu}^{\mathrm{t}}{ }_{3}-2,4,6\right)$ [1.821(3) $\AA]$ for which a small degree of $\mathrm{Ga}-\mathrm{O} \pi$-bonding has been suggested. ${ }^{14}$ In addition, although the heterocycle centroid$\mathrm{Ga}(1)-\mathrm{O}(1)$ angle is more acute than the ideal angle for $\mathrm{Ga}-$ $\mathrm{O} \pi$-bonding $\left(180^{\circ}\right)$, it is much more obtuse $\left(148.5^{\circ}\right)$ than the heterocycle centroid- $\mathrm{Ga}(1)-\mathrm{O}(1)^{\prime}$ angle $\left(126.2^{\circ}\right)$. It must be said, however, that due to the electronegativity differences between $\mathrm{Ga}$ and $\mathrm{O}$, the bonding between these two centres in $\mathbf{2}$ is probably largely ionic in character. Furthermore, the asymmetric nature of its $\mathrm{Ga}_{2} \mathrm{O}_{2}$ ring could arise from a distorting effect of the $\mathrm{O}$ $\mathrm{K}$ interaction [2.584(3) $\AA$ ], which is well within the established range of coordinate bonds of this type. ${ }^{15}$ The K-centres in 2 are additionally $\eta^{5}$-coordinated to the gallium heterocycle and chelated by a molecule of tmeda, as is the case in the dimeric solid state structure of $[\mathrm{K}(\mathrm{tmeda})][\mathbf{1}]$. The $\mathrm{K}-\mathrm{Ga}$ distances in the former [3.1383(16) $\AA$ ] are, however, considerably shorter than those in the latter [3.5318(18) A].$^{1}$ Another notable feature of the structure of $\mathbf{2}$ is the Ga..Ga separation of $2.608 \AA$, which is at the upper end of the range for Ga-Ga single bonds and very close to that in the related compound, [ $\mu$ O) $\left.\mathrm{Ga}\left\{[\mathrm{N}(\mathrm{Ar}) \mathrm{C}(\mathrm{Me})]_{2} \mathrm{CH}\right\}\right]_{2}[2.5989(3) \AA]^{10}$ As was proposed for that compound, the shortness of the $\mathrm{Ga} \cdots \mathrm{Ga}$ distance in 2 probably does not constitute an interaction, and arises from the fact that the ligation of the $\mathrm{Ga}$ centres by electronegative $\mathrm{N}$ - and $\mathrm{O}$-atoms increases their relative ionic nature and, thus, decreases their effective radii.

The molecular structure of $\mathbf{3}$ shows it to be dimeric, but in contrast to $\mathbf{2}$, the telluride ligands are essentially symmetrically bridging. The lengths of the $\mathrm{Ga}-\mathrm{Te}$ bonds (2.618 $\AA$ avge.) are close to the mean for all previously structurally characterised examples $(2.66 \AA)^{15}$ and comparable to those in related complexes, e.g. $\left[\left\{\kappa^{2}-\mathrm{C}, \mathrm{N}-\left(\mathrm{Me}_{3} \mathrm{Si}\right)_{2} \mathrm{C}(\mathrm{Ph}) \mathrm{C}\left(\mathrm{Me}_{3} \mathrm{Si}\right) \mathrm{N}\right\} \mathrm{Ga}(\mu-\mathrm{Te})\right]_{2}$ $[2.570(9) \AA] .{ }^{16}$ They are, however, significantly longer than in terminal tellurido complexes, e.g. $2.422(1) \AA$ in $\left[\left(\mathrm{Tp}^{\mathrm{t}_{\mathrm{Bu}}}\right) \mathrm{Ga}=\mathrm{Te}\right] .{ }^{9}$ In addition, the planar $\mathrm{Ga}_{2} \mathrm{Te}_{2}$ core of the complex possesses $\mathrm{Te}-\mathrm{Ga}-\mathrm{Te}$ and $\mathrm{Ga}-\mathrm{Te}-\mathrm{Ga}$ angles of $98.77(2)$ and $81.23(2)^{\circ}$ respectively, which are consistent with the larger covalent radius of Te over Ga. The size of the Te centres can also be used to

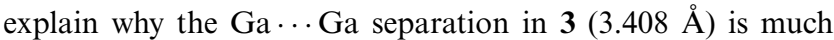
larger than that in $\mathbf{2}(2.608 \AA)$. Each potassium cation of $\mathbf{3}$ is coordinated by a molecule of THF, a Te lone pair and $\eta^{6}$ - and $\eta^{3}$-interactions from the arene substituents of opposing gallium heterocycles. Finally, the geometries of these essentially planar heterocycles are similar to those in $\mathbf{2}$, and contain distorted tetrahedral gallium centres.

Considering the success had oxidising the gallium centre of 1 with sources of elemental chalcogens, it was deemed appropriate to investigate similar reactions with dialkyl or diaryl dichalcogenides, REER. These were thought likely to oxidatively add to the $\mathrm{Ga}(\mathrm{I})$ centre of the gallium heterocycle. In this respect, it is somewhat surprising that, to the best of our knowledge, there are no examples of related reactions between REER and NHCs. Mixed success was had in this phase of the study, as treating $[\mathrm{K}(\mathrm{tmeda})][\mathbf{1}]$ with 1 one equiv. of either $\mathrm{Bu}^{\mathrm{t}} \mathrm{OOBu} \mathrm{u}^{\mathrm{t}}$ or $\mathrm{PhSeSePh}$ led to intractable mixtures of products, the identity of which could not be determined. In contrast, the oxidative addition reactions of $[\mathrm{K}($ tmeda $)][\mathbf{1}]$ with PhEEPh $(\mathrm{E}=\mathrm{Se}$ or $\mathrm{Te})$ proceeded cleanly to give the related complexes, $\mathbf{4}$ and $\mathbf{5}$, which differ only in the degree of solvation of their potassium cations (Scheme 1). These differences are derived from the 
Table 1 Crystal data for compounds $\mathbf{2 , 3}, \mathbf{4}$ and $\mathbf{5}$

\begin{tabular}{|c|c|c|c|c|}
\hline Compound & 2 & 3 & 4 & 5 \\
\hline Empirical formula & $\mathrm{C}_{64} \mathrm{H}_{104} \mathrm{Ga}_{2} \mathrm{~K}_{2} \mathrm{~N}_{8} \mathrm{O}_{2}$ & $\mathrm{C}_{60} \mathrm{H}_{88} \mathrm{Ga}_{2} \mathrm{~K}_{2} \mathrm{~N}_{4} \mathrm{O}_{2} \mathrm{Te}_{2}$ & $\mathrm{C}_{38} \mathrm{H}_{46} \mathrm{GaKN}_{2} \mathrm{Se}_{2}$ & $\mathrm{C}_{50} \mathrm{H}_{76} \mathrm{GaKN}_{2} \mathrm{O}_{3} \mathrm{Te}_{2}$ \\
\hline FW & 1235.19 & 1370.18 & 797.51 & 1117.15 \\
\hline$T / \mathrm{K}$ & $150(2)$ & $150(2)$ & $150(2)$ & $150(2)$ \\
\hline Crystal system & Triclinic & Monoclinic & Monoclinic & Monoclinic \\
\hline Space group & $P \overline{1}$ & $P 2(1) / n$ & $P 2(1) / c$ & $P 2(1) / c$ \\
\hline$a / \AA$ & $12.498(3)$ & $12.084(2)$ & $11.231(2)$ & $11.690(2)$ \\
\hline$b / \AA$ & $12.816(3)$ & $21.762(4)$ & $16.360(3)$ & $23.912(5)$ \\
\hline$c / \AA$ & $12.885(3)$ & $12.374(3)$ & $22.088(4)$ & $19.616(4)$ \\
\hline$a /^{\circ}$ & $83.87(3)$ & 90 & 90 & 90 \\
\hline$\beta /^{\circ}$ & $65.85(3)$ & $103.22(3)$ & $103.33(3)$ & $102.19(3)$ \\
\hline$\gamma /{ }^{\circ}$ & $64.02(3)$ & 90 & 90 & 90 \\
\hline$V / \AA^{3}$ & $1686.3(6)$ & $3167.8(11)$ & $3949.1(14)$ & $5359.7(18)$ \\
\hline$Z$ & 1 & 2 & 4 & 4 \\
\hline$\mu(M o-K \alpha) / m m^{-1}$ & 0.968 & 1.926 & 2.671 & 1.696 \\
\hline$F(000)$ & 660 & 1392 & 1624 & 2272 \\
\hline Reflns collected & 17102 & 19176 & 24621 & 51522 \\
\hline Independent reflns & 5836 & 5675 & 7200 & 10484 \\
\hline$R$ (int) & 0.0801 & 0.0720 & 0.0668 & 0.0942 \\
\hline Final $R_{1}, w R_{2}$ indices $[I>2 \sigma(I)]$ & $0.0642,0.1514$ & $0.0493,0.0985$ & $0.0406,0.0775$ & $0.0689,0.1643$ \\
\hline
\end{tabular}

solvents used for the crystallisation process, viz. hexane for $\mathbf{4}$ and diethyl ether for $\mathbf{5}$. Both complexes are very air sensitive and, interestingly, when $\mathbf{5}$ was treated with a stoichiometric amount of oxygen in solution or the solid state, the ditelluride, $\mathrm{Ph}_{2} \mathrm{Te}_{2}$, was obtained in high yield, along with other unidentified decomposition products.

The molecular structures of $\mathbf{4}$ and $\mathbf{5}$ are depicted in Figs. 3 and 4 , respectively. The geometries of the heterocycles in the anionic fragments of each, $\left[(\mathrm{PhE})_{2} \mathrm{Ga}\left\{[\mathrm{N}(\mathrm{Ar}) \mathrm{C}(\mathrm{H})]_{2}\right\}\right]^{-}$, are similar and both possess distorted tetrahedral gallium centres. As was the case with the structures of $\mathbf{2}$ and $\mathbf{3}$, the $\mathrm{Ga}-\mathrm{N}$ distances and $\mathrm{N}-$ $\mathrm{Ga}-\mathrm{N}$ angles of $\mathbf{4}$ and $\mathbf{5}$ are, respectively, considerably shorter and more obtuse that those in the free gallium(I) heterocycle $\left[\mathrm{Ga}-\mathrm{N}\right.$ avge. $=1.970 \AA$ 政 $\left.\mathrm{N}-\mathrm{Ga}-\mathrm{N}=83.02(11)^{\circ}\right] .{ }^{1}$ There are, however, significant differences between the structures of $\mathbf{4}$ and 5. For instance, the potassium cation in $\mathbf{4}$ is coordinated by lone pairs of two $\mathrm{SePh}$ fragments from different heterocycles. This leads to short and long K-Se interactions [K(1)-Se(2) 3.3241(10) $\left.\AA ; \mathrm{K}(1)-\mathrm{Se}(1)^{\prime} 3.4903(11) \AA\right]$ that lie in the normal range. ${ }^{15}$ In addition, $\eta^{4}$ - and $\eta^{6}$-interactions $(\mathrm{K}-\mathrm{C}<3.45 \AA$ ) with two heterocycle arene substituents lead to an infinite 1-dimensional polymeric structure for this complex. Although the $\mathrm{Ga}-\mathrm{Se}$ bond lengths differ [Ga(1)-Se(1) 2.4026(6) Å; Ga(1)-Se(2) 2.4301(7) $\AA$ ], both are close to the mean for all crystallographically characterised examples $(2.41 \AA) .{ }^{15}$

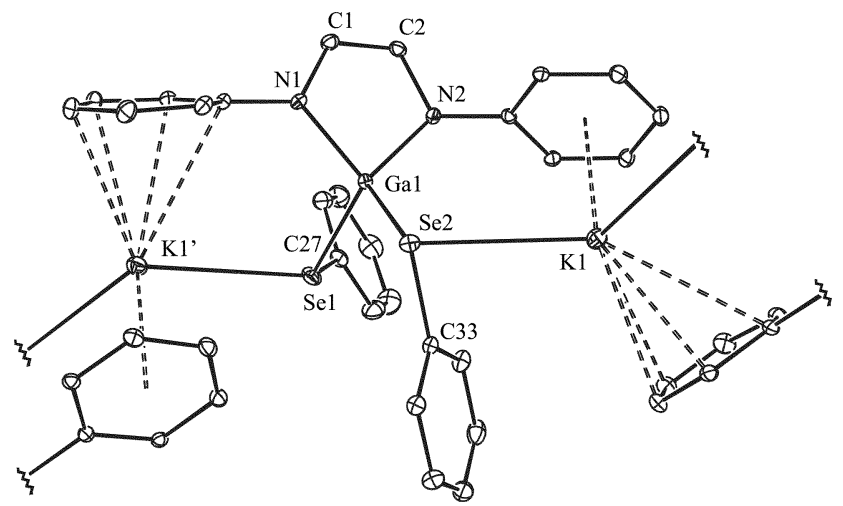

Fig. 3 Molecular structure of $\mathbf{4}$ (isopropyl groups removed for sake of clarity). Selected bond lengths $(\AA)$ and angles $\left({ }^{\circ}\right)$ : $\mathrm{Ga}(1)-\mathrm{N}(1) 1.912(3)$, $\mathrm{Ga}(1)-\mathrm{N}(2)$ 1.898(3), Ga(1)-Se(1) 2.4026(6), $\mathrm{Ga}(1)-\mathrm{Se}(2)$ 2.4301(7), $\mathrm{Se}(1)-\mathrm{C}(27)$ 1.923(4), C(1)-C(2) 1.336(4), $\mathrm{Se}(2)-\mathrm{K}(1)$ 3.3241(10), $\mathrm{Se}(1)-\mathrm{K}(1)^{\prime} 3.4903(11), \mathrm{N}(1)-\mathrm{Ga}(1)-\mathrm{N}(2)$ 88.91(11), N(1)-Ga(1)-Se(1) 111.19(8), N(1)-Ga(1)-Se(2) 116.19(9), Se(1)-Ga(1)-Se(2) 103.96(3), $\mathrm{Ga}(1)-\mathrm{Se}(1)-\mathrm{K}(1)^{\prime}$ 96.37(3), Ga(1)-Se(2)-K(1) 104.13(3). Symmetry operation used to generate equivalent atoms ': $-x+2, y-1 / 2,-z+$ $1 / 2$.

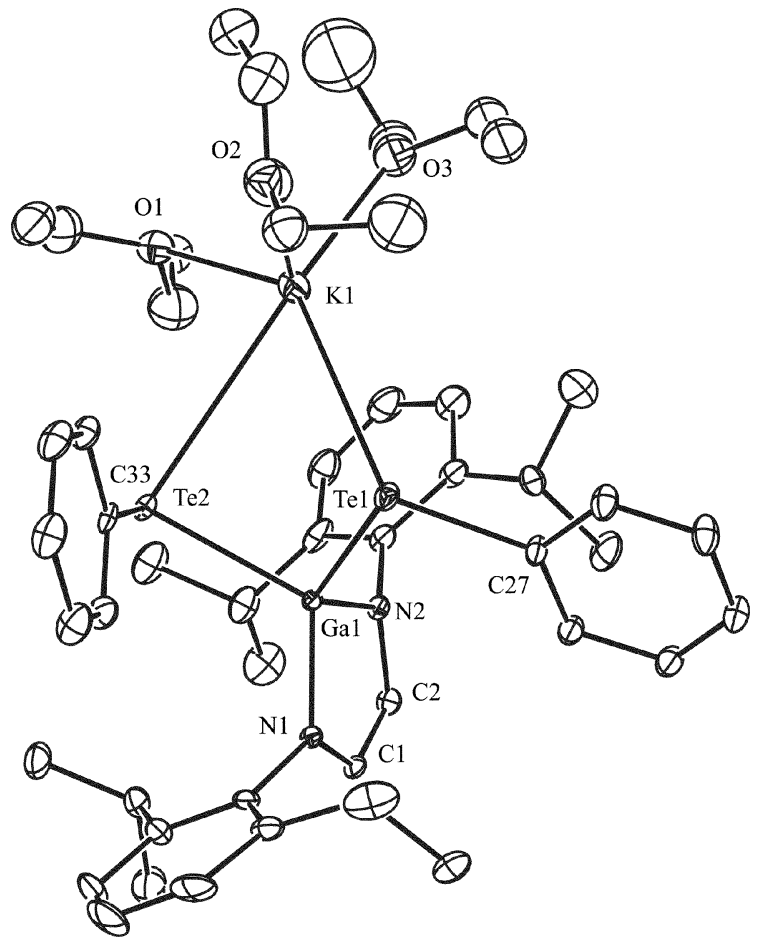

Fig. 4 Molecular structure of 5. Selected bond lengths $(\AA)$ and angles $\left({ }^{\circ}\right): \mathrm{Ga}(1)-\mathrm{N}(1) 1.896(6), \mathrm{Ga}(1)-\mathrm{N}(2) 1.900(6), \mathrm{Ga}(1)-\mathrm{Te}(1) 2.5785(12)$, $\mathrm{Ga}(1)-\mathrm{Te}(2) \quad 2.6577(10), \mathrm{Te}(1)-\mathrm{K}(1)$ 3.886(3), $\mathrm{Te}(2)-\mathrm{K}(1)$ 3.711(3), $\mathrm{C}(1)-\mathrm{C}(2) \quad 1.335(11), \quad \mathrm{N}(1)-\mathrm{Ga}(1)-\mathrm{N}(2)$ 87.9(2), $\mathrm{N}(1)-\mathrm{Ga}(1)-\mathrm{Te}(1)$ 121.56(18), $\quad \mathrm{N}(1)-\mathrm{Ga}(1)-\mathrm{Te}(2) \quad 118.63(18), \quad \mathrm{N}(2)-\mathrm{Ga}(1)-\mathrm{Te}(1)$ 119.27(19), N(2)-Ga(1)-Te(2) 115.50(18), Te(1)-Ga(1)-Te(2) 96.06(3), $\mathrm{Ga}(1)-\mathrm{Te}(1)-\mathrm{C}(27) \quad 103.9(2), \quad \mathrm{Ga}(1)-\mathrm{Te}(1)-\mathrm{K}(1) \quad 82.57(5), \quad \mathrm{K}(1)-$ $\mathrm{Te}(1)-\mathrm{C}(27)$ 127.5(2), Ga(1)-Te(2)-C(33) 94.77(18), Ga(1)-Te(2)-K(1) 85.12(5), $\mathrm{K}(1)-\mathrm{Te}(2)-\mathrm{C}(33) 102.3(2), \mathrm{Te}(1)-\mathrm{K}(1)-\mathrm{Te}(2)$ 61.62(4).

In contrast to $\mathbf{4}$, complex $\mathbf{5}$ is monomeric with its potassium cation chelated by both tellurium centres and coordinated by three molecules of diethyl ether. An examination of the $\mathrm{Ga}-\mathrm{Te}$ bond lengths $[\mathrm{Ga}(1)-\mathrm{Te}(1) 2.5785(12) \AA$ and $\mathrm{Ga}(1)-\mathrm{Te}(2) 2.6577(10) \AA]$ revealed them to be significantly different but, again, to lie within the normal range. ${ }^{15}$ This difference could allow 5 to described as an '-ate' complex of $\left[(\mathrm{PhTe}) \mathrm{Ga}\left\{[\mathrm{N}(\mathrm{Ar}) \mathrm{C}(\mathrm{H})]_{2}\right\}\right]$ and $\mathrm{KTePh}$. In line with this description is the difference in the two $\mathrm{K}-\mathrm{Te}$ bond lengths [Te(1)-K(1) 3.886(3) $\AA$ and $\mathrm{Te}(2)-\mathrm{K}(1) 3.711(3) \AA]$, the shorter of which is associated with the longer $\mathrm{Te}-\mathrm{Ga}$ interaction. Furthermore, the two $\mathrm{C}-\mathrm{Te}-\mathrm{Ga}$ angles in the complex are 
considerably different [C(27)-Te(1)-Ga(1) 103.9(2); C(33)$\left.\mathrm{Te}(2)-\mathrm{Ga}(1) 94.77(18)^{\circ}\right]$. Finally, the Te-Ga-Te angle [96.06(3) $\left.{ }^{\circ}\right]$ is markedly more acute than the corresponding $\mathrm{Se}-\mathrm{Ga}-\mathrm{Se}$ angle in $4\left[103.96(3)^{\circ}\right]$, though this may be due to chelation of the potassium cation by both Te-centres in the former.

\section{Conclusion}

In summary, the reactivity of an anionic gallium(I) NHC analogue, $[\mathrm{K}($ tmeda $)]\left[: \mathrm{Ga}\left\{[\mathrm{N}(\mathrm{Ar}) \mathrm{C}(\mathrm{H})]_{2}\right\}\right]$, towards sources of elemental chalcogens and diorgano-dichalcogenides has been investigated. This has given rise to four crystallographically characterised complexes in which the gallium centres have been oxidised by the chalcogen precursor. Of these, the dimeric oxide and telluride complexes, $\mathbf{2}$ and $\mathbf{3}$, display significant structural differences, which in the former may suggest a small degree of $\mathrm{Ga}-\mathrm{O} \pi$-bonding. Similarly, differences were observed between the structures of the polymeric phenyl selenide and monomeric phenyl telluride complexes, $\mathbf{4}$ and $\mathbf{5}$, the latter of which can be described as an '-ate' complex. This study further highlights both similarities and differences between the reactivity of the gallium heterocycle, $\left[: \mathrm{Ga}\left\{[\mathrm{N}(\mathrm{Ar}) \mathrm{C}(\mathrm{H})]_{2}\right\}\right]^{-}$, and that of the valence isoelectronic $\mathrm{N}$-heterocyclic carbene class of ligand.

\section{Experimental}

\section{General considerations}

All manipulations were carried out using standard Schlenk and glove box techniques under an atmosphere of high purity argon. THF was distilled over potassium whilst diethyl ether and hexane were distilled over $\mathrm{Na} / \mathrm{K}$ then freeze/thaw degassed prior to use. ${ }^{1} \mathrm{H}$ and ${ }^{13} \mathrm{C}$ NMR spectra were recorded on either Bruker DXP400 or Jeol Eclipse 300 spectrometers and were referenced to the residual ${ }^{1} \mathrm{H}$ resonances of the solvent used. Mass spectra were recorded using a VG Fisons Platform II instrument operating under APCI conditions, or were obtained from the EPSRC National Mass Spectrometry Service at Swansea University. IR spectra were recorded using a Nicolet 510 FT-IR spectrometer as Nujol mulls between $\mathrm{NaCl}$ plates. Melting points were determined in sealed glass capillaries under argon, and are uncorrected. Reproducible microanalyses could not be obtained on any of the complexes due to their extremely air sensitive nature. In all cases, however, spectroscopic data pointed to the bulk materials having a purity of $>98 \%$. $[\mathrm{K}($ tmeda $)]\left[\mathrm{Ga}\left\{[\mathrm{N}(\mathrm{Ar}) \mathrm{C}(\mathrm{H})]_{2}\right\}\right]^{1}$ and $(\mathrm{Te}) \mathrm{PEt}_{3}{ }^{17}$ were synthesised by literature procedures. $\mathrm{N}_{2} \mathrm{O}$ was obtained from BOC whilst all other chemicals were obtained from Aldrich and used as supplied.

$[\mathbf{K}(\text { tmeda })]_{2}\left[(\boldsymbol{\mu}-\mathrm{O}) \mathbf{G a}\left\{[\mathbf{N}(\mathbf{A r}) \mathbf{C}(\mathbf{H})]_{2}\right\} \mathbf{l}_{2}, \mathbf{2}\right.$. To a solution of [K(tmeda)][:Ga $\left.\left\{[\mathrm{N}(\mathrm{Ar}) \mathrm{C}(\mathrm{H})]_{2}\right\}\right](0.40 \mathrm{~g}, 0.68 \mathrm{mmol})$ in diethyl ether $(25 \mathrm{~mL})$ at $-78{ }^{\circ} \mathrm{C}$ was added $\mathrm{N}_{2} \mathrm{O}(0.68 \mathrm{mmol})$ as a gas. The reaction mixture was stirred for $12 \mathrm{~h}$ to give a colourless solution. Concentration and placement at $-35^{\circ} \mathrm{C}$ overnight yielded colourless crystals of $2(0.08 \mathrm{~g}, 19 \%)$. Mp: $174-176{ }^{\circ} \mathrm{C}$ (dec.); ${ }^{1} \mathrm{H}$ NMR (400 MHz, $\left.\mathrm{C}_{6} \mathrm{D}_{6}, 298 \mathrm{~K}\right): \delta 1.16\left(\mathrm{~d}, 24 \mathrm{H},{ }^{3} J_{\mathrm{HH}}=\right.$ $\left.6.9 \mathrm{~Hz}, \mathrm{CH}_{3}\right), 1.33\left(\mathrm{~d}, 24 \mathrm{H},{ }^{3} J_{\mathrm{HH}}=6.9 \mathrm{~Hz}, \mathrm{CH}_{3}\right), 2.11(\mathrm{~s}, 24 \mathrm{H}$, $\left.\mathrm{NCH}_{3}\right), 2.32\left(\mathrm{~s}, 8 \mathrm{H}, \mathrm{NCH}_{2}\right), 3.85$ (sept., $8 \mathrm{H},{ }^{3} J_{\mathrm{HH}}=6.9 \mathrm{~Hz}$, $\mathrm{CH}), 5.73(\mathrm{~s}, 4 \mathrm{H}, \mathrm{NCH}), 7.19\left(\mathrm{t}, 4 \mathrm{H},{ }^{3} J_{\mathrm{HH}}=7.5 \mathrm{~Hz}, p-\mathrm{ArH}\right)$, $7.36\left(\mathrm{~d}, 8 \mathrm{H},{ }^{3} J_{\mathrm{HH}}=7.5 \mathrm{~Hz}, m-\mathrm{ArH}\right) ;{ }^{13} \mathrm{C}$ NMR $(100.6 \mathrm{MHz}$, $\left.\mathrm{C}_{6} \mathrm{D}_{6}, 298 \mathrm{~K}\right): \delta 23.6\left(\mathrm{CHCH}_{3}\right), 25.0\left(\mathrm{CHCH}_{3}\right), 27.7(\mathrm{CH}), 57.9$ $\left(\mathrm{NCH}_{3}\right), 65.6\left(\mathrm{NCH}_{2}\right), 122.6(\mathrm{CN}), 122.9(m-\mathrm{ArC}), 123.4(p-$ ArC), 142.7 (o-ArC), 146.4 (ipso-ArC); IR $v / \mathrm{cm}^{-1}$ (Nujol): 1619 m, $1571 \mathrm{~s}, 1323 \mathrm{~s}, 1202 \mathrm{~s}, 1099 \mathrm{~s}, 1021 \mathrm{~s}, 874 \mathrm{~m}$; MS/APCI m/z (\%): $377\left[\{\mathrm{~N}(\mathrm{Ar}) \mathrm{C}(\mathrm{H})\}_{2} \mathrm{H}^{+}, 18\right], 116\left[\mathrm{tmedaH}^{+}, 100\right]$.

$[\mathbf{K}(\mathbf{T H F})]_{2}\left[(\boldsymbol{\mu}-\mathbf{T e}) \mathbf{G a}\left\{[\mathbf{N}(\mathbf{A r}) \mathbf{C}(\mathbf{H})]_{2}\right\}\right]_{2}, 3$. To a solution of $[\mathrm{K}$ (tmeda) $]\left[: \mathrm{Ga}\left\{[\mathrm{N}(\mathrm{Ar}) \mathrm{C}(\mathrm{H})]_{2}\right\}\right](0.35 \mathrm{~g}, 0.58 \mathrm{mmol})$ at $-78{ }^{\circ} \mathrm{C}$ in THF $(30 \mathrm{~mL})$ was added a solution of $(\mathrm{Te}) \mathrm{PEt}_{3}(0.12 \mathrm{~g}$, $0.58 \mathrm{mmol})$ in THF $(10 \mathrm{~mL})$ over $15 \mathrm{~min}$. The resultant solution was warmed to room temperature and stirred for $24 \mathrm{~h}$. The solvent was removed in vacuo and the residue extracted into hexane $(30 \mathrm{~mL})$. Filtration, concentration and placement at $-35^{\circ} \mathrm{C}$ overnight yielded red crystals of $3(0.26 \mathrm{~g}, 68 \%) . \mathrm{Mp}>$ $300{ }^{\circ} \mathrm{C} .{ }^{1} \mathrm{H}$ NMR $\left(300.52 \mathrm{MHz}, \mathrm{C}_{6} \mathrm{D}_{6}\right): \delta 1.15\left(\mathrm{~d}, 24 \mathrm{H},{ }^{3} J_{\mathrm{HH}}=\right.$ $\left.6.6 \mathrm{~Hz}, \mathrm{CH}_{3}\right), 1.25\left(\mathrm{~d}, 24 \mathrm{H},{ }^{3} J_{\mathrm{HH}}=6.6 \mathrm{~Hz}, \mathrm{CH}_{3}\right), 1.38(\mathrm{~m}$, $8 \mathrm{H}, \mathrm{THF}), 3.51$ (m, $8 \mathrm{H}, \mathrm{THF}), 3.71$ (sept., $8 \mathrm{H},{ }^{3} J_{\mathrm{HH}}=$ $6.6 \mathrm{~Hz}, \mathrm{CH}), 6.32(\mathrm{~s}, 4 \mathrm{H}, \mathrm{NCH}), 7.07-7.19(\mathrm{~m}, 12 \mathrm{H}, \mathrm{ArH})$; ${ }^{13} \mathrm{C}$ NMR $\left(75.57 \mathrm{MHz}, \mathrm{C}_{6} \mathrm{D}_{6}, 298 \mathrm{~K}\right): \delta 24.3\left(\mathrm{CHCH}_{3}\right), 25.3$ $\left(\mathrm{CHCH}_{3}\right), 25.5\left(\mathrm{CH}_{2}\right), 28.1(\mathrm{CH}), 67.5\left(\mathrm{OCH}_{2}\right), 122.7(\mathrm{CN})$, 123.1 (m-ArC), 123.6 (p-ArC), 145.7 (o-ArC), 150.3 (ipso-ArC); IR (Nujol): $1664 \mathrm{w}, 1457 \mathrm{~s}, 1377$ s, $1261 \mathrm{~m}, 1099 \mathrm{~m}, 796 \mathrm{~m}$, $721 \mathrm{w} \mathrm{cm}^{-1}$; MS/MALDI $m / z(\%): 377\left[\{\mathrm{~N}(\mathrm{Ar}) \mathrm{C}(\mathrm{H})\}_{2} \mathrm{H}^{+}, 100\right]$.

$\left[\mathbf{K}\left[(\mathbf{P h S e})_{2} \mathbf{G a}\left\{[\mathbf{N}(\mathbf{A r}) \mathbf{C}(\mathbf{H})]_{2}\right\}\right]_{\infty}, \quad\right.$ 4. To a solution of $[\mathrm{K}(\mathrm{tmeda})]\left[: \mathrm{Ga}\left\{[\mathrm{N}(\mathrm{Ar}) \mathrm{C}(\mathrm{H})]_{2}\right\}\right](0.35 \mathrm{~g}, 0.58 \mathrm{mmol})$ in diethyl ether $(20 \mathrm{~mL})$ at $-78^{\circ} \mathrm{C}$ was added a solution of $\mathrm{Ph}_{2} \mathrm{Se}_{2}(0.20 \mathrm{~g}$, $0.64 \mathrm{mmol})$ in diethyl ether $(10 \mathrm{~mL})$ over $10 \mathrm{~min}$. The resultant solution was warmed to room temperature and stirred for $24 \mathrm{~h}$, whereupon volatiles were removed in vacuo and the residue extracted into hexane $(30 \mathrm{~mL})$. Filtration, concentration and placement at $-35{ }^{\circ} \mathrm{C}$ overnight yielded orange-red crystals of $4(0.22 \mathrm{~g}, 48 \%)$. Mp $168-174{ }^{\circ} \mathrm{C}(\mathrm{dec}) .{ }^{1} \mathrm{H}$ NMR $(400 \mathrm{MHz}$, $\left.\mathrm{C}_{6} \mathrm{D}_{6}\right): \delta 1.13\left(\mathrm{~d}, 12 \mathrm{H},{ }^{3} J_{\mathrm{HH}}=6.0 \mathrm{~Hz}, \mathrm{CH}_{3}\right), 1.24(\mathrm{~d}, 12 \mathrm{H}$, ${ }^{3} J_{\mathrm{HH}}=6.0 \mathrm{~Hz}, \mathrm{CH}_{3}$ ), 3.45 (sept., $4 \mathrm{H},{ }^{3} J_{\mathrm{HH}}=6.0 \mathrm{~Hz}, \mathrm{CH}$ ), $6.20(\mathrm{~s}, 2 \mathrm{H}, \mathrm{NCH}), 7.07-7.64(\mathrm{~m}, 16 \mathrm{H}, \mathrm{ArH}) ;{ }^{13} \mathrm{C} \mathrm{NMR}$ $\left(75.57 \mathrm{MHz}, \mathrm{C}_{6} \mathrm{D}_{6}, 298 \mathrm{~K}\right): \delta 24.1\left(\mathrm{CHCH}_{3}\right), 24.4\left(\mathrm{CHCH}_{3}\right)$, $28.0(\mathrm{CH}), 123.1(\mathrm{CN}), 123.7$ (m-ArC), 124.7 (p-ArC), 127.4 (PhSe), 128.5 (PhSe), 130.7 (PhSe), 140.0 (PhSe), 142.5 (o-ArC), 144.8 (ipso-ArC); IR (Nujol): $1666 \mathrm{w}, 1573 \mathrm{~m}, 1459$ ms, 1377 m, 1350 w, $1326 \mathrm{w}, 1261 \mathrm{~s}, 1099 \mathrm{~s}, 1019 \mathrm{~s}, 801 \mathrm{~s}, 765 \mathrm{w}, 733 \mathrm{~m}$, 689 w, $668 \mathrm{~m}, 667 \mathrm{w}, 665 \mathrm{w} \mathrm{cm}^{-1}$; MS/ES - ve: $m / z(\%): 681$ $\left[(\mathrm{PhSe})(\mathrm{Se}) \mathrm{Ga}\left\{[\mathrm{N}(\mathrm{Ar}) \mathrm{C}(\mathrm{H})]_{2}\right\}^{-}, 22\right], 156\left[\mathrm{PhSe}^{-}, 100\right]$.

$\left.\left[\mathbf{K}\left(\mathrm{OEt}_{2}\right)_{3}\right]\left[(\mathbf{P h T e})_{2} \mathbf{G a}\{\mathbf{I N}(\mathbf{A r}) \mathbf{C}(\mathbf{H})]_{2}\right\}\right], 5$. To a solution of $[\mathrm{K}(\mathrm{tmeda})]\left[: \mathrm{Ga}\left\{[\mathrm{N}(\mathrm{Ar}) \mathrm{C}(\mathrm{H})]_{2}\right\}\right](0.35 \mathrm{~g}, 0.58 \mathrm{mmol})$ in diethyl ether $(20 \mathrm{~mL})$ at $-78^{\circ} \mathrm{C}$ was added a solution of $\mathrm{Ph}_{2} \mathrm{Te}_{2}(0.24 \mathrm{~g}$, $0.58 \mathrm{mmol})$ in $\mathrm{Et}_{2} \mathrm{O}(10 \mathrm{~mL})$. The resultant solution was warmed to room temperature and stirred for $24 \mathrm{~h}$, whereupon volatiles were removed in vacuo and the residue extracted into hexane $(30 \mathrm{~mL})$. Filtration, concentration and placement at $-35{ }^{\circ} \mathrm{C}$ overnight yielded orange crystals of $5(0.37 \mathrm{~g}, 57 \%)$. Mp 152 $156{ }^{\circ} \mathrm{C}(\mathrm{dec}) .{ }^{1} \mathrm{H}$ NMR $\left(400 \mathrm{MHz}, \mathrm{C}_{6} \mathrm{D}_{6}\right): \delta 1.15\left(\mathrm{~d}, 12 \mathrm{H},{ }^{3} J_{\mathrm{HH}}=\right.$ $\left.6.5 \mathrm{~Hz}, \mathrm{CH}_{3}\right), 1.28\left(\mathrm{~d}, 12 \mathrm{H},{ }^{3} J_{\mathrm{HH}}=6.5 \mathrm{~Hz}, \mathrm{CH}_{3}\right), 1.39(\mathrm{t}, 18 \mathrm{H}$, $\left.{ }^{3} J_{\mathrm{HH}}=7.1 \mathrm{~Hz}, \mathrm{CH}_{2} \mathrm{CH}_{3}\right), 4.09\left(\mathrm{q}, 12 \mathrm{H},{ }^{3} J_{\mathrm{HH}}=7.1 \mathrm{~Hz}, \mathrm{OCH}_{2}\right)$, 3.49 (sept., $\left.4 \mathrm{H},{ }^{3} J_{\mathrm{HH}}=6.6 \mathrm{~Hz}, \mathrm{CH}\right), 6.25(\mathrm{~s}, 2 \mathrm{H}, \mathrm{NCH}), 7.07-$ $7.64(\mathrm{~m}, 16 \mathrm{H}, \mathrm{ArH}) ;{ }^{13} \mathrm{C} \mathrm{NMR}\left(75.57 \mathrm{MHz}, \mathrm{C}_{6} \mathrm{D}_{6}, 298 \mathrm{~K}\right)$ : $\delta 14.0\left(\mathrm{CH}_{2} \mathrm{CH}_{3}\right), 24.8\left(\mathrm{CHCH}_{3}\right), 25.3\left(\mathrm{CHCH}_{3}\right), 28.9(\mathrm{CH})$, $69.8\left(\mathrm{OCH}_{2}\right), 123.8(\mathrm{CN}), 124.2(m-\mathrm{ArC}), 125.1$ ( $p$-ArC), 128.4 (PhTe), 129.2 (PhTe), 132.5 (PhTe), 141.1 (PhTe), 143.8 (o-ArC), 144.2 (ipso-ArC); IR (Nujol): 1573 m, 1454 s, 1377 s, $1321 \mathrm{~m}$, $1259 \mathrm{~s}, 1225 \mathrm{~s}, 1102 \mathrm{~m}, 1016 \mathrm{~m}, 997 \mathrm{w}, 934 \mathrm{w}, 799 \mathrm{~s}, 756 \mathrm{~s}, 728 \mathrm{~s}$, $690 \mathrm{~s}, 650 \mathrm{w} \mathrm{cm}^{-1}$; MS/EI $m / z(\%): 377\left[\{\mathrm{~N}(\mathrm{Ar}) \mathrm{C}(\mathrm{H})\}_{2} \mathrm{H}^{+}, 100\right]$.

\section{X-Ray crystallography}

Crystals of 2, 3, 4 and 5 suitable for X-ray structural determination were mounted in silicone oil. Crystallographic measurements were made using a Nonius Kappa CCD diffractometer. The structures were solved by direct methods and refined on $F^{2}$ by full matrix least squares (SHELX97) ${ }^{18}$ using all unique data. One molecule of potassium coordinated diethyl ether (that containing $\mathrm{O}(3)$ ) in the structure of $\mathbf{5}$ was found to be disordered over two sites. This disorder was successfully modelled and the atoms of both disordered sets were subsequently refined isotropically. Only the atoms of the higher occupancy set are displayed in Fig. 4. All other non-hydrogen atoms in each structure were refined anisotropically with $\mathrm{H}$-atoms included in calculated positions (riding model). Crystal data, details of data collections and refinement are given in Table 1.

CCDC reference numbers: 268557-268560. 
See http://www.rsc.org/suppdata/dt/b5/b505085e/ for crystallographic data in CIF or other electronic format.

\section{Acknowledgements}

We thank the EPSRC for financial support (partial studentship for MK and postdoctoral fellowship for RJB). The EPSRC mass spectrometry service at Swansea University is also thanked.

\section{References}

1 R. J. Baker, R. D. Farley, C. Jones, M. Kloth and D. M. Murphy, J. Chem. Soc., Dalton Trans., 2002, 3844.

2 (a) E. S. Schmidt, A. Jockisch and H. Schmidbaur, J. Am. Chem. Soc., 1999, 121, 9758; (b) E. S. Schmidt, A. Schier and H. Schmidbaur, J. Chem. Soc., Dalton Trans., 2001, 505.

3 (a) e.g. N. Kuhn and A. Al-Sheikh, Coord. Chem. Rev., 2005, 249, 829; (b) W. Kirmse, Eur. J. Org. Chem., 2005, 237; (c) W. A. Herrmann, Angew. Chem., Int. Ed., 2002, 41, 1291; (d) C. J. Carmalt and A. H. Cowley, Adv. Inorg. Chem., 2000, 50, 1; (e) D. Bourissou, O. Guerret, F. P. Gabai and G. Bertrand, Chem. Rev., 2000, 100, 39, and references therein.

4 (a) R. J. Baker, C. Jones and D. M. Murphy, Chem. Commun., 2005, 1339; (b) R. J. Baker, C. Jones, M. Kloth and J. A. Platts, Organometallics, 2004, 23, 4811; (c) R. J. Baker, C. Jones and J. A. Platts, Dalton Trans., 2003, 3673; (d) R. J. Baker, C. Jones and J. A. Platts, J. Am. Chem. Soc., 2003, 125, 10534; (e) R. J. Baker, C. Jones, M. Kloth and J. A. Platts, Angew. Chem., Int. Ed., 2003, 43, 2660.
5 R. J. Baker and C. Jones, Coord. Chem. Rev., DOI: 10.1016/ j.ccr.2004.12.016, and references therein.

6 N. Kuhn, G. Henkel and T. Kratz, Chem. Ber., 1993, 126, 2047.

7 M. Haaf, A. Schmiedl, T. A. Schmedake, D. R. Powell, A. J. Millevolte, M. Denk and R. West, J. Am. Chem. Soc., 1998, 120, 12714.

8 (a) e.g. M. C. Kuchta and G. Parkin, Coord. Chem. Rev., 1998, 176, 232; (b) J. P. Oliver, J. Organomet. Chem., 1995, 500, 269and references therein.

9 (a) M. C. Kuchta and G. Parkin, J. Chem. Soc., Dalton Trans., 1998, 2279; (b) M. C. Kuchta and G. Parkin, Inorg. Chem., 1997, 36, 2492.

10 N. J. Hardman and P. P. Power, Inorg. Chem., 2001, 40, 2474.

11 W. Uhl, M. Benter, W. Saak and P. G. Jones, Z. Anorg. Allg. Chem., 1998, 624, 1622.

12 Y. Ping, H. Fan, V. Jancik, H. W. Roesky and R. Herbst-Irmer, Angew. Chem., Int. Ed., 2004, 43, 6190.

13 J. Storre, C. Schnitter, H. W. Roesky, H.-G. Schmidt, M. Noltemeyer, R. Fleischer and D. Stalke, J. Am. Chem. Soc., 1997, 119, 7505.

14 M. A. Petrie, M. M. Olmstead and P. P. Power, J. Am. Chem. Soc., 1991, 113, 8704.

15 As determined from a survey of the Cambridge Crystallographic Database, April, 2005.

16 K. S. Klimek, J. Prust, H. W. Roesky, M. Noltemeyer and H.-G. Schmidt, Organometallics, 2001, 20, 2047.

17 R. A. Zingaro, B. H. Steeves and K. Irgolic, J.Organomet. Chem., $1965, \mathbf{4}, 320$.

18 G. M. Sheldrick, SHELX-97, University of Göttingen, 1997. 